\title{
POTENCIAL DE APLICAÇÃO DE INFRAESTRUTURA VERDE NA BACIA DE DRENAGEM DO CÓRREGO BELINI
}

POTENTIAL FOR APPLICATION OF THE GREEN INFRASTRUCTURE IN THE DRAINAGE BASIN OF THE BELINI STREAM

\author{
Maria Cristina Santana Pereira ${ }^{1}$, José Rodolfo Scarati Martins², \\ RAfael Sampaio MARTINS ${ }^{3}$ \\ ${ }^{1}$ Engenheira Ambiental, Mestra em Recursos Hídricos, Doutoranda em Recursos Hídricos na Escola \\ Politécnica da USP, São Paulo, SP. E-mail: maripereira@usp.br \\ 2 Professor associado do Departamento de Engenharia Hidráulica e Ambiental da Escola Politécnica \\ da USP, São Paulo, SP. E-mail: scarati@usp.br \\ ${ }^{3}$ Arquiteto e Urbanista graduado pela Faculdade de Arquitetura do Mackenzie, São Paulo, SP. \\ E-mail: arquitetorafaelsampaio@gmail.com
}

\section{RESUMO}

Este estudo analisa a potencialidade de aplicação de infraestrutura verde na bacia de drenagem do córrego Belini. É uma área ocupada por residências que, embora sejam de alto padrão, apresenta problemas, poucos em relação ao resto da cidade, mas típicos de áreas urbanas, como inundações e precariedade dos sistemas de mobilidade. Devido à presença de muitas áreas verdes, é uma região propícia para a implementação de infraestrutura verde. Assim sendo, será apresentado um plano com diretrizes, que foi adaptado do zoneamento ambiental desenvolvido por Schutzer e aplicado por Bonzi, em busca de que os processos naturais convivam de forma mais harmoniosa com a ocupação da bacia.

Palavras-chave: Infraestrutura verde; Córrego Belini; Área Urbana; Zoneamento Ambiental; Bacia de Drenagem.

\section{ABSTRACT}

The scope of this work is to analyze the potential of green infrastructure application in the Belini Stream drainage basin. It is an area occupied by residences that, although being of a high standard of living, presents problems, few compared to the rest of the 
city, but typical of urban areas, like floods and precarious mobility systems. The existence of several green areas makes it adequate to the implementation of green infrastructure. Therefore, it is presented a plan with guidelines adapted from the environmental zoning developed by Schutzer and applied by Bonzi, which aims to promote the coexistence of natural processes and occupation of that basin in a more harmonious way.

Keywords: Green Infrastructure; Belini Stream; Urban Area; Environmental Zoning; Drainage Basin.

\section{INTRODUÇÃO}

Este trabalho analisará a potencialidade de aplicação de infraestrutura verde na bacia de drenagem do córrego Belini, afluente do rio Pinheiros, fazendo tal, por meio da integração das propriedades ambientais dos dispositivos de Infraestrutura Verde (IEV) disposta na bacia do córrego Belini seguindo as premissas do estudo de compartimento ambiental desenvolvido por Schutzer (2012) e aplicado por Bonzi (2015).

O crescimento populacional e a expansão urbana desordenada geram impactos causando desequilíbrio do meio ambiente como um todo. Este desequilíbrio se dá por meio de diversos fatores, tais como a impermeabilização do solo, a poluição do ar, o uso intenso de materiais condutores de energia térmica no meio urbano, o aumento das edificações e redução das superfícies vegetadas (TUCCI, 2007; MOTA, 2008).

A urbanização desordenada, como a que aconteceu na cidade de São Paulo no século XX, suprimi áreas verdes, retifica e canaliza rios minando dessa forma uma série de serviços ambientais. Os serviços ambientais amplamente difundidos e providos pelas áreas verdes são: conforto térmico, controle da umidade, sombreamento, retenção de poluentes, redução de ruídos, manutenção da biodiversidade, aumento da permeabilidade, efeitos paisagísticos (MAGALHÃES, 2013) que ainda ressalta a necessidade da gestão participativa nos espaços para a garantia da qualidade paisagística, a manutenção e aprimoramento das funções ambientais, de lazer, esporte, recreação e educação ambiental.

Dada a importância dessas áreas para o regime hídrico, tem-se que a urbanização, dada sua característica, provoca alteração em diversas fases dos ciclos naturais e 
especificamente do ciclo hidrológico, alterando diretamente a dinâmica natural dos corpos d'água e das superfícies das bacias hidrográficas (TUCCI, 2007; MOTA,2008).

\section{CONTEXTO HISTÓRICO DA ÁREA DE ESTUDO}

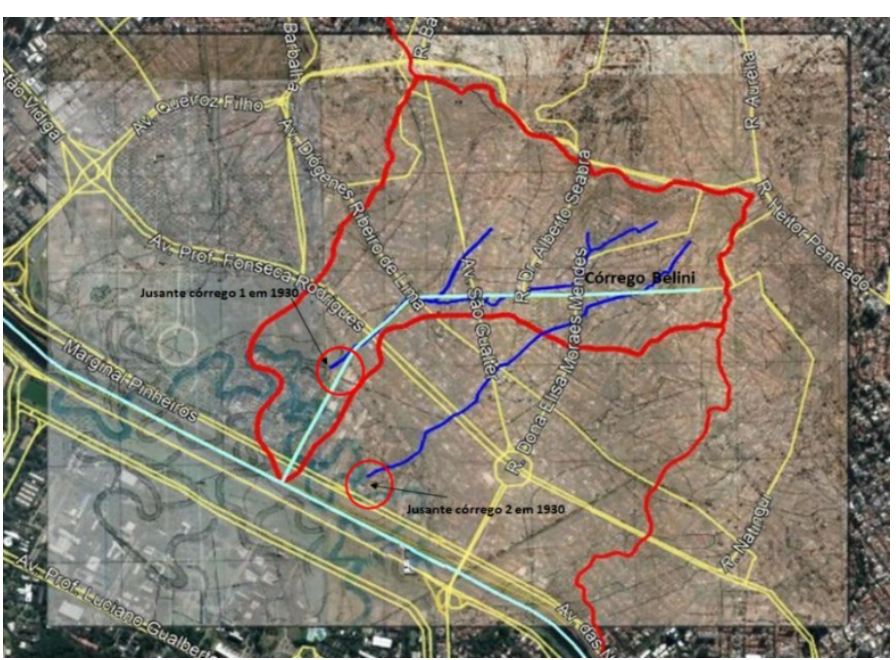

FIGURA 01. Bacia de drenagem do Belini sobreposta pela imagem do SARA 1930. Elaboração dos autores a partir da base do Google Earth e Geosampa (2018)

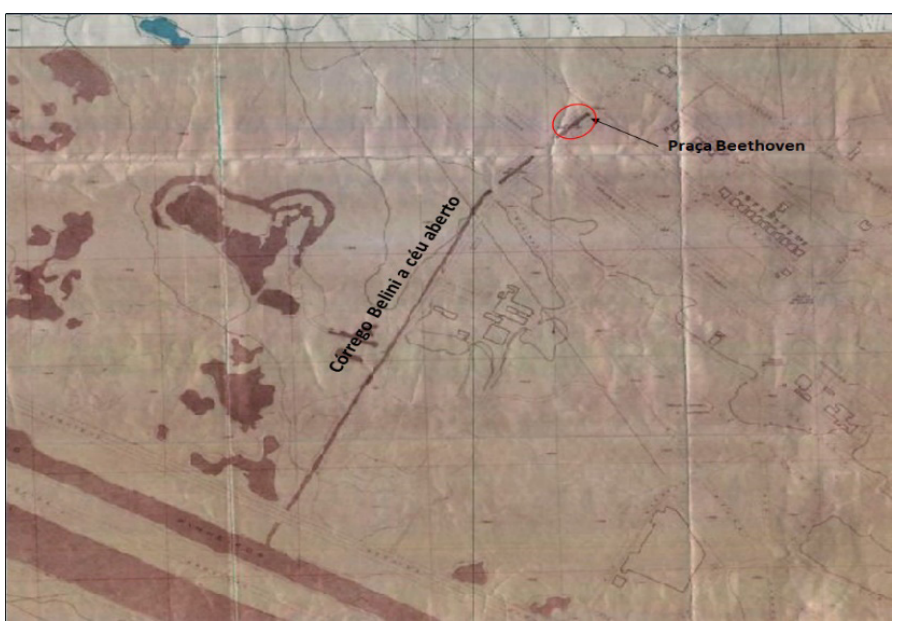

FIGURA 2. O canal aberto na figura é o córrego Belini, hoje tamponado. Elaboração dos autores a partir da base do Geosampa (2018)
A área de drenagem do córrego Belini compreende uma região que, nas imagens do levantamento aerofotogramétrico realizado pela empresa Societá Anônima de Rilevamenti Aerofotogrammetrici (SARA) em 1930, apresenta dois córregos e toda a região de jusante que atualmente corresponde à faixa abaixo da Avenida Diógenes Ribeiro de Lima, antiga estrada da Boiada fazia parte do leito maior do rio Pinheiros, por onde este meandrava e inundava nos períodos de cheia, A Figura 1 apresenta a imagem do SARA de 1930 sobre a imagem de 2017 do Google Earth.

A região de jusante do córrego Belini, na imagem da Vasp Cruzeiro do ano de 1954 apresenta a região com as suas águas drenadas em um canal, que atualmente é o córrego Belini atualmente tamponado, este está aberto desde a praça Beethoven até desaguar no rio Pinheiros, como apresentado na Figura 2. 
A região apresentada no final do córrego Belini a jusante da Avenida Faria Lima é uma região com histórico de inundações, a Figura 3 (a) apresenta em amarelo a área de inundações históricas fornecidas pela Secretaria de Infraestrutura e Obras de São Paulo (SIURB) e a Figura 3 (b) apresenta uma imagem de um alagamento ocorrido na região de 2013, o local é em frente ao colégio Santa Cruz.

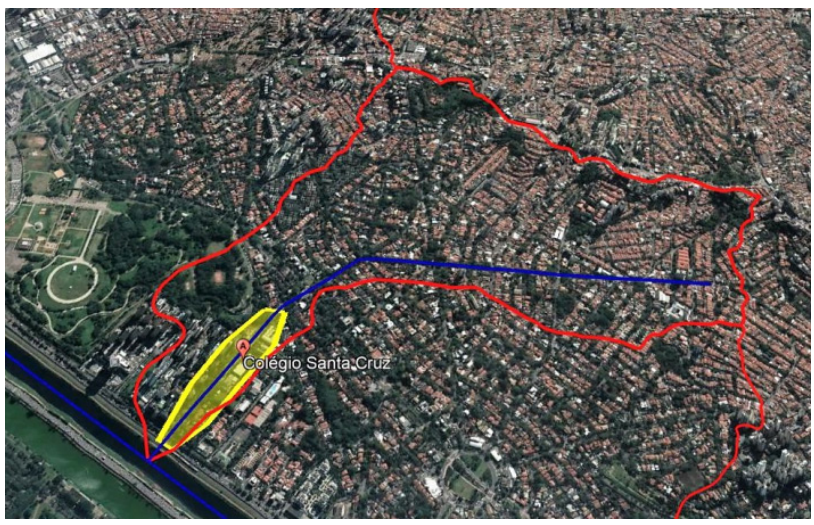

(a)

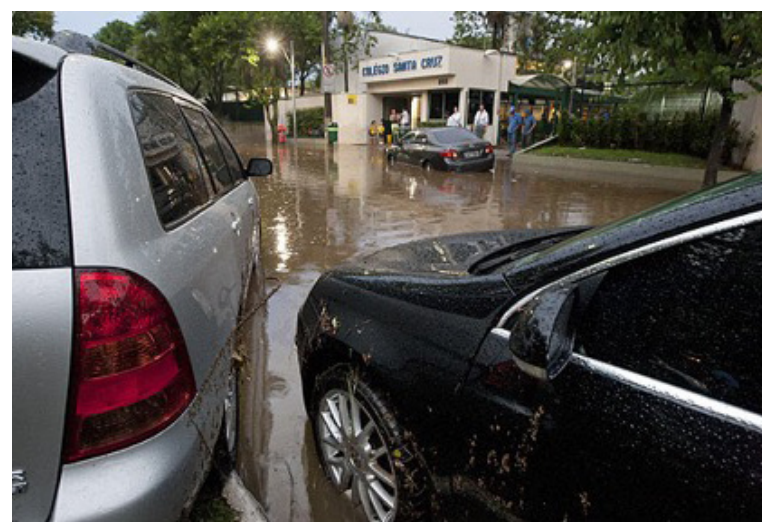

(b)

FIGURA 3. (a) região com histórico de inundações. Fonte: (SIURB) (b) inundação em frente ao colégio Santa Cruz. Fonte: Folha de São Paulo. Elaboração dos autores a partir da base do Google Earth (2018).

O traçado da cidade, que confina e tampona rios e córregos da cidade criou uma população que desconhece seus cursos d'água (CARINNA; ALMIR, 2016) e não sabe como lidar com a água no meio urbano, pois somente se depara com água na rua, na sua grande maioria das vezes, nas situações de inundações e alagamento. Esse total desconhecimento se deve à falta de ações para que a água faça parte do meio urbano seja para lazer ou mesmo para a contemplação.

Essa mesma população precisa se apropriar dos espaços abertos e praças da região. Nos seus $2,1 \mathrm{~km}^{2}$ da bacia de drenagem do córrego Belini há 26 praças, demonstrando ser uma região rica em áreas verdes, mas que modificou e omitiu seus cursos d’água.

Mendonça (2015) sinaliza que apesar do bairro ser agradável e arborizado seus espaços são vazios, tanto pelo fato de suas calçadas serem estreitas e projetadas para o olhar de quem passa de automóvel, quanto pelo fato de seu comércio estar concentrado em determinados eixos. Também aponta que a diretora da associação de 
moradores do bairro relata que não se encontra "espírito de comunidade", não há o costume de conversar com os vizinhos. Além disso, as pessoas parecem não desejar estar na rua, e menos ainda de serem abordadas.

Diante o exposto, o objetivo é elaborar um elenco de alternativas constituídas de dispositivos de infraestrutura verde de forma a minimizar os problemas encontrados na região, tanto na estrutura física do local quanto na forma de induzir a população a se apropriar dos espaços ofertados pela região.

\section{O DESENHO AMBIENTAL E INFRAESTRUTURA VERDE (IEV)}

No planejamento e desenho ambiental, a Infraestrutura verde pode ser compreendida como uma rede de áreas verdes naturais e outros espaços abertos que conservam valores e funções ecológicas, sustentam o ar e água limpos e fornecem ampla variedade de benefícios para as pessoas e vida selvagem que deverão nortear as ações de planejamento e desenvolvimento territoriais de forma a garantir a existência de processos vivos (FRANCO, 2010).

Dispositivos como infraestrutura verde inseridas no contexto urbano "mimetizam funções ecológicas e hidrológicas dos ambientes naturais" (CORMIER; PELLEGRINO, 2008).

Este trabalho será desenvolvido a partir de uma infraestrutura verde baseada na compartimentação ambiental da paisagem e o zoneamento ambiental com base nos processos naturais que fornecem subsídios para que a sociedade mantenha certa estabilidade de sua base biofísica. Assim, optar-se-á por propor alternativas que contemplem questões ligadas a drenagem urbana, premissa oriunda da engenharia, bem como a prestação de outros serviços sistêmicos que possam ser ofertados a paisagem urbana, trabalhando dessa forma com infraestrutura verde multifuncional, como deve ser.

A proposta aqui apresentada faz parte de um trabalho que está sendo desenvolvido com o engajamento da população da região estudada, que vem atuando com ações de cunho ecosocial na busca da sustentabilidade. Essa participação maciça e ativa da população é o ferramental que propiciará a melhoria da escolha dos dispositivos aqui apresentados por meio de discussão e envolvimento ativo na aplicação dos dispositivos. 


\section{INFRAESTRUTURA VERDE (IEV) - DISPOSITIVOS}

\section{Jardim de Chuva}

Os jardins de chuva, também conhecidos por biorretenção, são uma técnica que usa as características do paisagismo para promover a retenção e/ou tratamento da água pluvial. São formados por uma área com depressão constituída de material poroso, sob uma superfície vegetada. Essas áreas têm frequentemente um poço de infiltração subterrâneo para favorecer a infiltração, principalmente em solos argilosos e também drenos para permitir o escoamento do excesso de água. Os jardins de chuva propiciam a recarga de águas subterrâneas, a remoção de poluentes e a detenção de escoamento. É uma solução eficaz em estacionamentos ou áreas urbanas, onde o espaço verde é limitado EPA (2013).

O solo tratado previamente com composto e demais insumos que aumentam a sua porosidade, atua como uma esponja sugando a água, ao mesmo tempo que microorganismos e bactérias no solo removem os poluentes oriundos do escoamento superficial. A vegetação, que faz parte da cobertura, é responsável pelo aumento da evapotranspiração e remoção de poluentes (MOURA, 2014). Já o fato da água ser totalmente infiltrada ou vertida está relacionado às condições geotécnicas do solo, devendo ainda ser dimensionados extravasores para os altos picos de escoamento superficial. Na Figura 4 são apresentados exemplos de jardim de chuva.
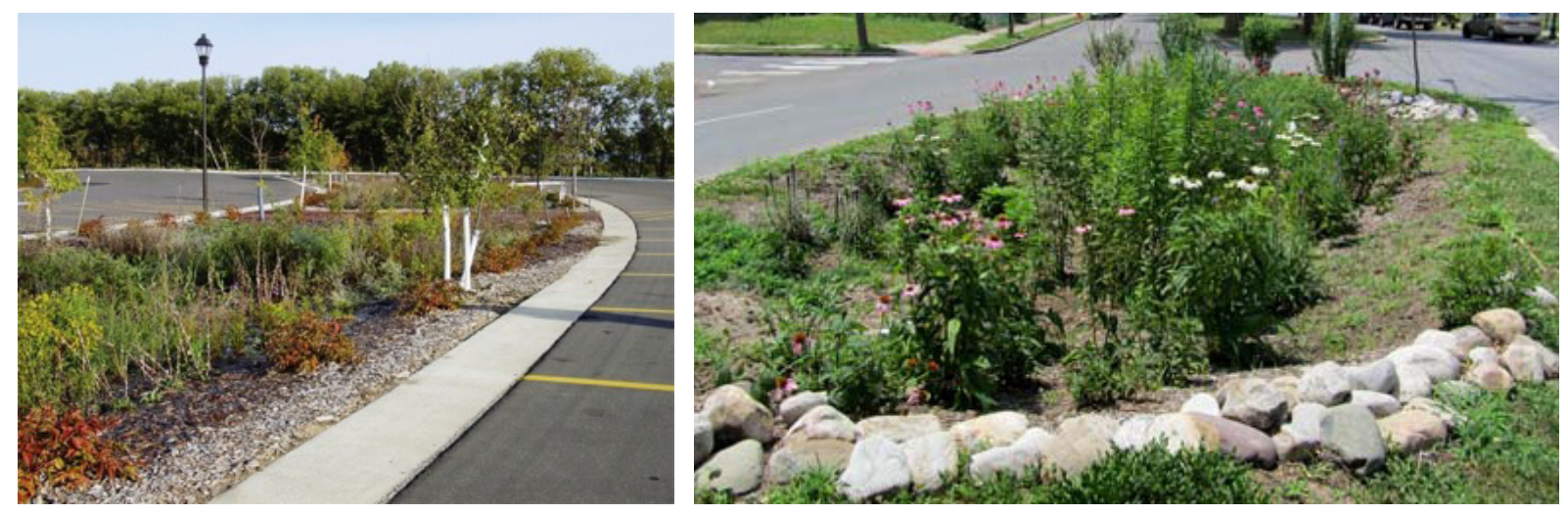

FIGURA 4. Exemplos de jardim de chuva. Fonte: (NRCS, 2013; UCONN, 2018)

\section{Canteiros Pluviais}

Canteiros pluviais são pequenos dispositivos com as mesmas características de jardins de chuva para o tratamento da água pluvial. Semelhantes aos jardins de chuva, 


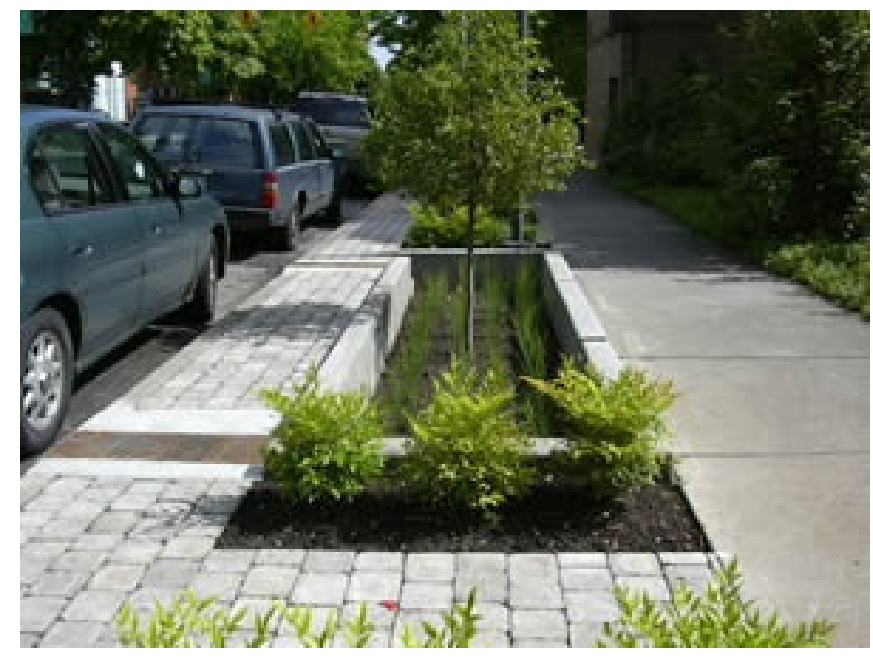

FIGURA 5. Canteiro pluvial em Portland. Fonte: Environmental Service, 2018

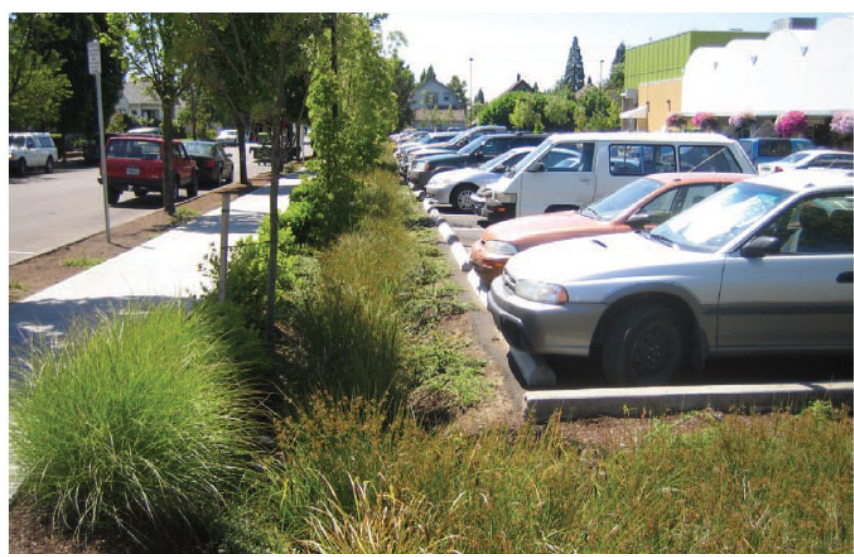

FIGURA 6. Biovaleta do estacionamento do New Seasons Market em Portland. Fonte: CORMIER, PELLEGRINO, 2008. mas em tamanhos reduzidos, compactados em pequenos espaços urbanos (MOURA,2014) A Figura 5 apresenta um exemplo de canteiro pluvial. É ideal para ser implementados em calçadas, canteiros centrais de vias e em locais com pouca disponibilidade de espaço.

\section{Biovaletas}

São faixas lineares rebaixadas, compostas por vegetação, solo e outros elementos que atuam como filtro realizando a despoluição da água e armazenam a água por determinado período retardando a velocidade do escoamento superficial (CORMIER; PELLEGRINO, 2008).

São semelhantes aos jardins de chuva, mas geralmente são depressões lineares constituídas de vegetação, solo e elementos que filtram a água, limpando-a e aumentando seu tempo de escoamento, dirigindo este para aos jardins de chuva (MOURA, 2014).

As biovaletas podem ser utilizadas em regiões íngremes pois é possível dividi-las em células escalonadas, configurando uma escada hidráulica com fundo plano. São ideais para serem implementadas em calçadas e em locais estreitos com pouca disponibilidade de espaço. A Figura 6 apresenta um exemplo de biovaleta. 


\section{Microrreservatórios (Barris de Chuva e Cisternas)}

Os microrreservatórios têm a função de colher a água da chuva para reutilização. Podem ser tanto os chamados barris de chuva quanto as chamadas cisternas ou 'piscininhas'. Estas últimas são objeto de legislação em algumas cidades. Barris de chuva são estruturas colocadas fora da edificação, próximas à descarga de calhas do telhado, para armazenar o escoamento da cobertura para uso posterior na rega do gramado e jardim. As cisternas permitem o armazenamento da água da chuva em volumes significativamente maiores em tanques fabricados ou em áreas de armazenamento subterrâneo (EPA, 2013). Na Figura 7, seguem exemplos de barris de chuva e cisterna.
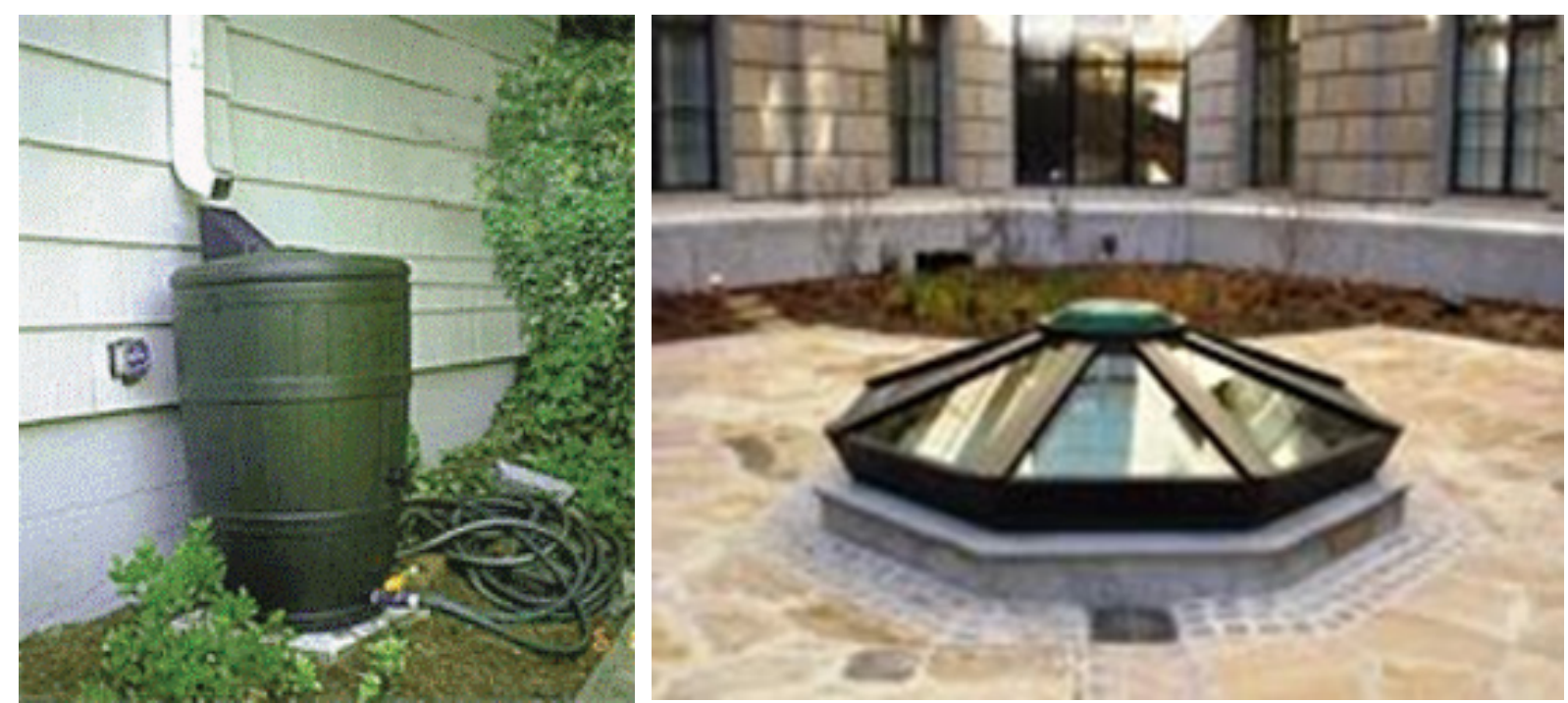

FIGURA 7. Barril de chuva e Cisterna. Fonte: EPA, (2013).

Segundo O'Loughlin (1995) apud Martins (2004), os microrreservatórios simulam o armazenamento natural. Além disso, representam uma forma justa de resolver o problema do escoamento superficial produzido no lote, visto que o proprietário ou modificador do lote é o responsável pelo incremento da vazão e deve arcar com os custos de manter as condições pré-existentes.

Os barris de chuva e as cisternas são dispositivos de baixo custo de implantação para a reservação de água e, além de reduzirem o volume do escoamento superficial, retardam e diminuem o pico de vazão. 


\section{Telhados Verdes}

Essa técnica consiste em utilizar uma cobertura vegetal nos topos de casas e edifícios para retardar e reter o escoamento superficial, como mostrado na Figura 8. No Brasil, é também conhecida como Cobertura Verde Leve (CVL) e telhado verde.

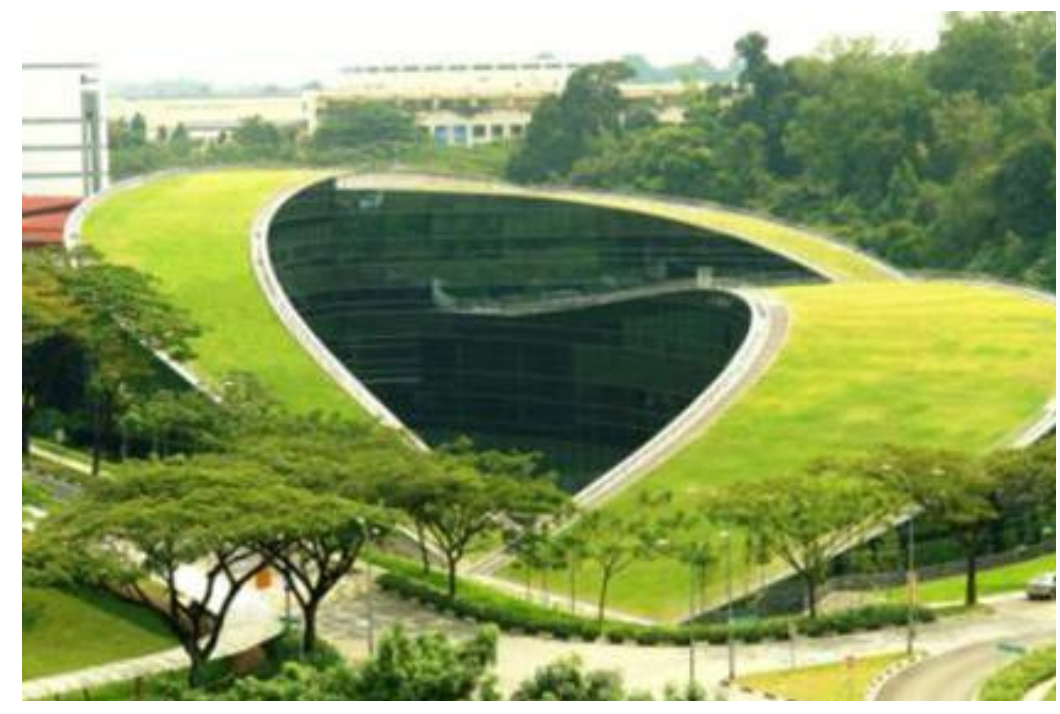

FIGURA 8. Telhado verde. Fonte: ANANDASIVAM, CHEONG, 2008.

No telhado vegetalizado, parte da água precipitada é infiltrada na superfície e a outra retorna por meio da evaporação. Capuccini (2010) ressalta que os telhados verdes podem reter até $60 \%$ da água precipitada e ainda podem dar ao edifício uma proteção térmica, contribuindo para o isolamento da edificação. A Figura 9 ilustra a diferença de escoamento entre um telhado verde e um telhado tradicional.

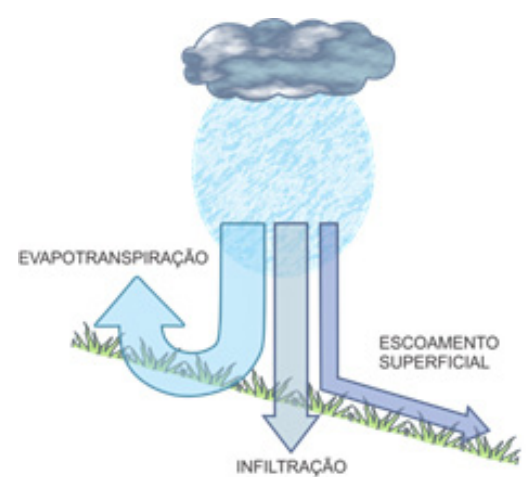

TELHADO VERDE

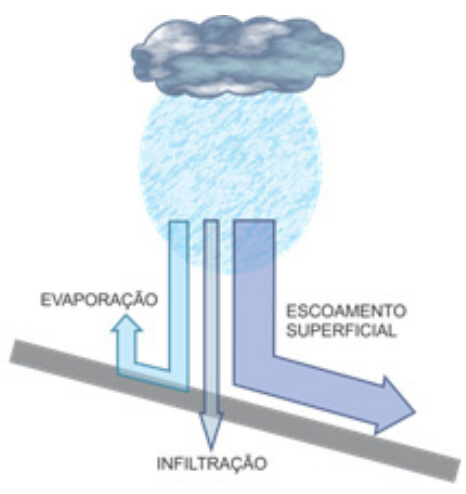

TELHADO CONVENCIONAL
FIGURA 9. Comparação de escoamentos em um telhado verde e em um telhado tradicional. Fonte: adaptado de Ohnuma Júnior (2008). Elaboração dos autores. 
Essa técnica pode ser implantada isoladamente ou se estender ao planejamento de uma área. Podem ser utilizados telhados planos ou dotados de ligeira declividade, inferior a $5 \%$.

\section{Pavimentos Permeáveis}

Pavimentos permeáveis são dispositivos hidráulicos que permitem a redução do escoamento em passeios, estacionamentos, quadras de esporte e ruas de pouco tráfego (MARQUES, 2006). Isso se dá em diferentes níveis:

- Pavimentos dotados de revestimentos superficiais permeáveis, possibilitando a redução da velocidade do escoamento superficial, a retenção temporária de pequenos volumes na própria superfície do pavimento e a infiltração de parte das águas pluviais;

- Pavimentos dotados de estrutura porosa, onde é efetuada a detenção temporária das águas pluviais, provocando o amortecimento de vazões e a alteração no desenvolvimento temporal dos hidrogramas;

- Pavimentos dotados de estrutura porosa e de dispositivos de facilitação da infiltração, onde ocorre tanto a detenção temporária das águas pluviais quanto a infiltração de parte delas. Obtém-se assim o amortecimento de vazões, a alteração temporal dos hidrogramas e a redução dos volumes escoados.

A Figura 10 apresenta exemplos de pavimentos permeáveis em estacionamentos.
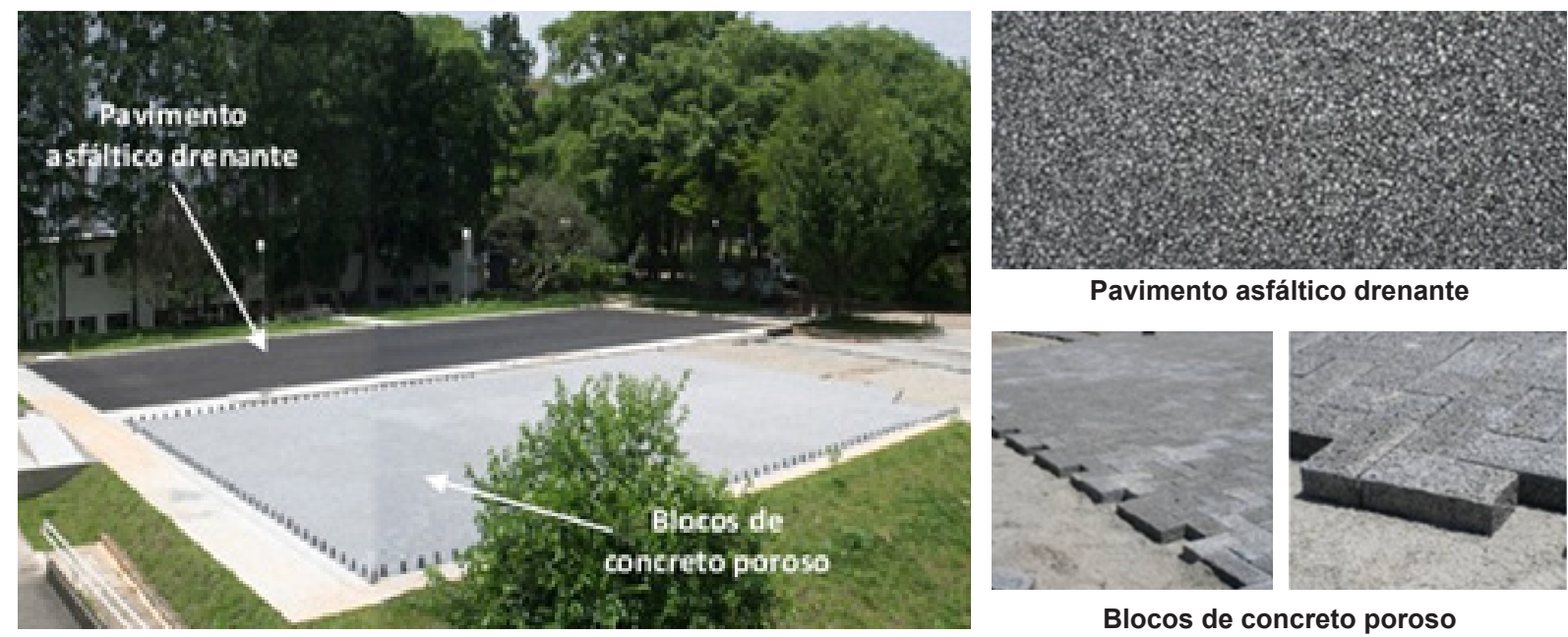

Pavimento asfáltico drenante
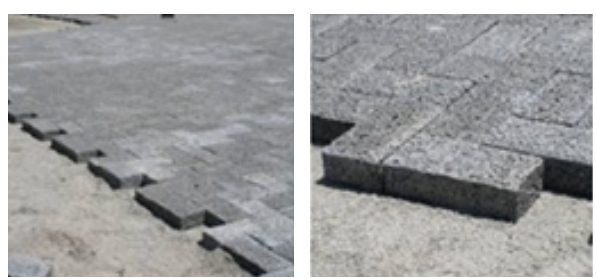

Blocos de concreto poroso

FIGURA 10. Exemplo de pavimentos permeáveis em estacionamento Fonte: (VIRGILIIS, 2009). 


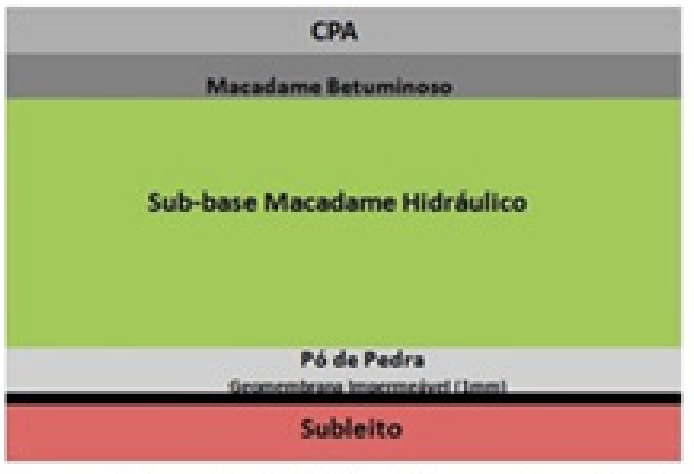

Concreto Asfáltico Poroso tipo CPA

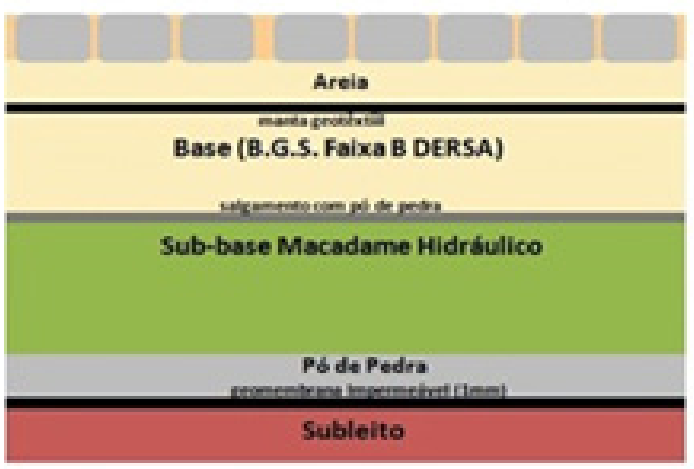

Blocos Intertravados de Concreto

FIGURA 11. Perfil da área revestida com pavimento permeável. Fonte: Virgillis (2009); Pinto (2011)
Podem ser constituídos por asfalto poroso, concreto poroso ou blocos de concreto perfurados, (URBORNAS; STAHRE, 1992).

Em ambos os casos são necessários filtros de transição ou geotêxtil para impedir a passagem de finos para a camada granular inferior, na Figura 11 são apresentadas as seções transversais de cada um dos módulos desta medida como os implantados no estacionamento do $\mathrm{CTH}$, na Universidade de São Paulo (USP), apresentado na Figura 10.

Segundo Araújo (1999), os pavimentos de asfalto poroso e de concreto poroso são construídos de forma similar aos pavimentos convencionais, tendo como diferença a retirada da fração

fina do agregado na mistura. Os pavimentos de blocos de concreto são construídos pela intercomunicação modular e suas células abertas são preenchidas com material granular, como areia e pedregulho, ou vegetação rasteira.

\section{Parques Lineares}

Os parques lineares são áreas destinadas à conservação e a preservação dos recursos naturais, tem como principal característica a capacidade de interligar fragmentos florestais e outros elementos encontrados em uma paisagem, assim como os corredores ecológicos. Neste tipo de parque têm-se a agregação de funções de uso humano, expressas principalmente por atividades de lazer e como rotas de locomoção humana não motorizada, compondo desta forma princípios de desenvolvimento sustentável (GIORDANO, 2004 apud FRIEDRICH, 2007). 
Os parques lineares atendem interesses diversos:

- Manejo das águas pluviais com a manutenção da área de várzea maior dos rios e córregos, pois serve de espaço de inundação durante os períodos de chuvas intensas;

- Parte de projeto de recuperação ambiental ao longo de rios e lagos;

- Espaços de recreação e revitalização ao longo de trilhas abandonadas;

- Como corredores naturais, ao longo de rios possibilitando o deslocamento de espécies;

- Rotas cênicas ou históricas, ao longo de estradas, rodovias, rios e lagos;

Bonzi (2015) afirma que córregos desenterrados acompanhados da criação de parque linear reabilitam alguns processos naturais e funções ecossistêmicas de sua várzea natural de inundação. A Figura 12 apresenta o parque linear Caulim, em Parelheiros, São Paulo.

Uma abordagem mais ampla do parque linear como elemento de requalificação ambiental urbana é o conceito da trama verde-azul, na qual os corpos hídricos e os parques adjacentes se interligam permitindo, além das vantagens já citadas, a recuperação de um maior número de elos da cadeia ecossistêmica Falkenmark et al. (2006) e Bergé et al. (2016).

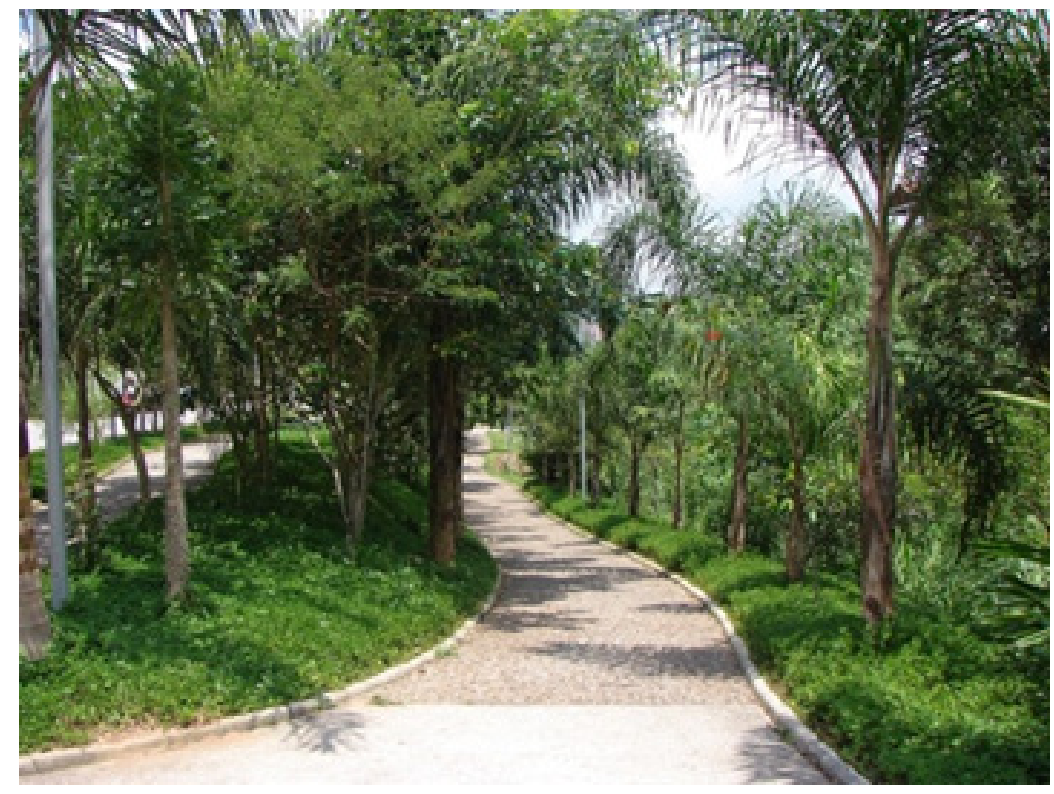

FIGURA 12. Parque linear Caulim, em Parelheiros. Fonte: PMSP, 2011. 
Renaturalização, Revitalização ou Recuperação de corpos d'água?

Silva (2015), traz a questão dos diferentes graus de intervenção a ser adotada em corpos d'água, sendo que a definição para cada uma dessas intervenções é:

- Renaturalizar - ação que visa o restabelecimento das relações entre o corpo d’água e a paisagem de modo a retorna-lo à condição natural, ou o mais próximo possível;

- Revitalizar - visa o restabelecer as relações entre o corpo d'água e a paisagem de forma funcional, isto é, reintroduzir o canal na paisagem revivendo-o, sem privar outros usos;

- Recuperação - busca o restabelecimento das condições físicas, químicas e biológicas do corpo d'água mínimas para que se atinja condições sanitárias satisfatórias, isto é. garantir a despoluição do corpo d’água.

Para Pinkham (1999), a expressão mais radical da infraestrutura verde é o conceito de "daylighting", que se refere a recuperação de córregos enterrados em galerias de águas subterrâneas.

E para cada condição de corpo d'água, Silva (2015) estabeleceu uma relação entre a condição atual do corpo d'água e o seu potencial de intervenção, apresentada na Tabela 1.

Tabela 1 - Corpos d'água e seu potencial de intervenção. Fonte: Silva (2015)

\begin{tabular}{|c|c|c|c|c|}
\hline \multicolumn{2}{|c|}{ Classificação do estado atual do corpo d'água } & $\begin{array}{c}\text { Potêncial para } \\
\text { renaturalização }\end{array}$ & $\begin{array}{l}\text { Potêncial para } \\
\text { revitalização }\end{array}$ & $\begin{array}{c}\text { Potêncial para } \\
\text { recuperação }\end{array}$ \\
\hline \multirow{3}{*}{$\begin{array}{c}\text { Sem } \\
\text { canalização }\end{array}$} & Dentro de fragmento florestal & Alto & Alto & Alto \\
\hline & $\begin{array}{l}\text { Com faixa de vegetação nas } \\
\text { margens }\end{array}$ & Alto & Alto & Alto \\
\hline & Em área de interesse social & Médio & Médio & Alto \\
\hline \multirow{3}{*}{$\begin{array}{l}\text { Canalizado } \\
\text { (Aberto) }\end{array}$} & $\begin{array}{l}\text { Com faixa de vegetação nas } \\
\text { margens }\end{array}$ & Médio & Médio & Alto \\
\hline & $\begin{array}{l}\text { Margens ocupadas por viário ou } \\
\text { imóveis }\end{array}$ & Médio & Médio & Alto \\
\hline & Em área de interesse social & Baixo & Médio & Alto \\
\hline \multirow{2}{*}{$\begin{array}{l}\text { Canalizado } \\
\text { (Fechado) }\end{array}$} & $\begin{array}{l}\text { Sob canteiro ou faixa de } \\
\text { vegetação }\end{array}$ & Baixo & Médio & Alto \\
\hline & Sob viário ou imóveis & Baixo & Médio & Alto \\
\hline
\end{tabular}




\section{O ZONEAMENTO AMBIENTAL}

No zoneamento ambiental é uma evolução do compartimento de relevo desenvolvida especificamente para ser aplicada em áreas de ocupação humana densa. Apresenta a ideia de valores de uso e de ocupação do relevo para a sociedade, indicando a fragilidade e a aptidão de cada compartimento do relevo em responder as funções urbanas (SCHUTZER, 2012; BONZI,2015).

O zoneamento ambiental parte da análise geomorfológica proposta por Aziz Ab' Sáber (1969), apresentado na Figura 13.

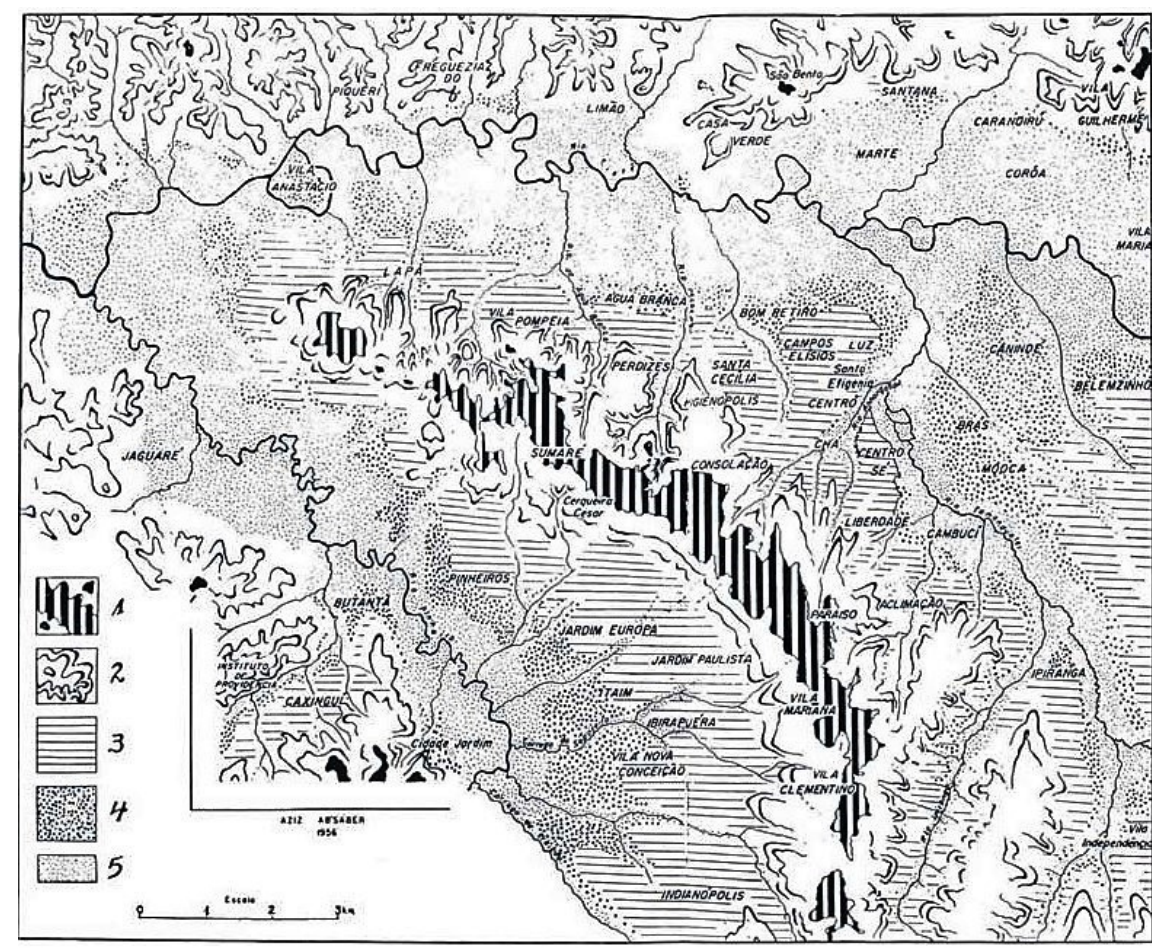

Legenda

1- Espigão Central (800-820m);

2 - Altas colinas e espigões secundários (750-795m);

3 - Terraços fluviais do níve intermediário (745-750m);

4 - Baixos terraços fluviais dos vales do Pinheiros, Tietê e seus afluentes principais (725-730m); 5 - Planícies dos aluviais do

Tietê-Pinheiros e seus afluentes

(720-722m)

FIGURA 13. Mapa geomorfológico esquemático do sítio urbano de São Paulo. Fonte: Ab'Sáber (1957).

Schutzer (2012) sabendo das capacidades ambientais e urbanas diante dos processos naturais e suas possibilidades para a ocupação elaborou a compartimentação do relevo da região para efeitos de desenho ambiental. A Figura 14 apresenta o esboço da compartimentação do relevo de São Paulo. 


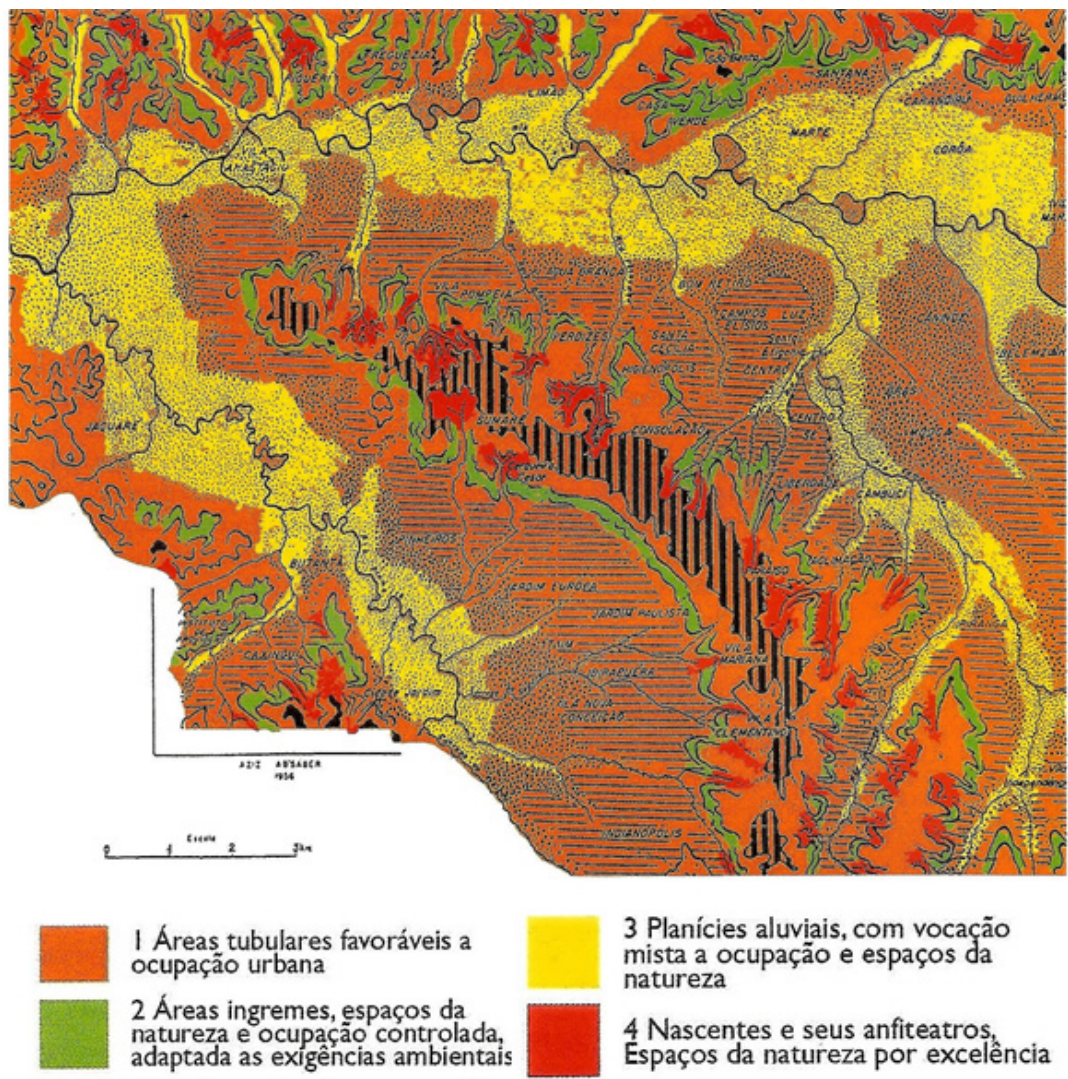

FIGURA 14. Esboço da compartimentação do relevo de São Paulo. Fonte: Massafumi; Parma; Schutzer, (2005) apud Schutzer (2012).

Pode-se identificar quatro compartimentos de relevo na região entre os rios Tietê e Pinheiros, sendo:

\section{Áreas tabulares e relativamente planas favoráveis à ocupação urbana}

Área predominante, satisfatória à ocupação urbana. Variação topográfica de 725-730 até 800-820. Regiões onde o processo de infiltração predomina sobre o escoamento superficial. Local onde deve ser mantido porcentagem satisfatória de permeabilidade favorecendo os processos de infiltração, percolação, filtragem das águas pluviais, para abastecimentos das nascentes e também favorável ao retardamento do escoamento superficial nos canais de drenagem.

\section{Áreas íngremes de vertentes de altas colinas}

Regiões de talude com declividade acentuada pouco suscetível à infiltração com o predomínio do escoamento superficial 
Dada sua característica deveriam ser mantidas em estado natural, com arborização densa, ideal para praças e parques com o uso de técnicas que favoreçam o controle do escoamento superficial e a acessibilidade das pessoas, como terraceamento. Schutzer (2012) ressalta que quando há ocupação urbana deve-se evitar o parcelamento do solo e impermeabilização excessiva evitando-se, assim o aumento do escoamento superficial.

\section{Nascentes}

Anfiteatros de drenagem, local que abriga nascentes, para Schutzer (2012) são espaços destinados primordialmente à natureza. Local de predominância do escoamento superficial, com propensão à erosão, deslizamentos e assoreamento de canais. A umidade do local deve ser preservada com o a permeabilidade e densa vegetação de anfiteatro.

\section{Planícies aluviais ou várzeas (Fundos de vale)}

Regiões baixas e planas, região sedimentar e receptora de água dos demais compartimentos. É uma área de predominância da infiltração, com armazenamento de água temporária ou constante, o nível do lençol freático se situa entre um e três metros abaixo da superfície. Schutzer (2012) enfatiza que o manejo dessa região é dependente das condições de permeabilidade do solo e do escoamento superficial das áreas mais elevadas.

A Tabela 2 apresenta um resumo das áreas do zoneamento ambiental, como já definido (SCHUTZER, 2012; BONZI,2015) onde é mais favorável a aplicação de determinada infraestrutura verde de acordo com os dispositivos apresentados. 
Tabela 2 - Síntese para a aplicação dos dispositivos de infraestrutura verde de acordo com o zoneamento ambiental. Fonte: Bonzi, 2015. Adaptado pelos autor

\begin{tabular}{|c|c|c|c|c|}
\hline Tipologia Zona ambiental & $\begin{array}{l}\text { Áreas } \\
\text { tabulares }\end{array}$ & $\begin{array}{l}\text { Áreas } \\
\text { íngremes }\end{array}$ & $\begin{array}{l}\text { Áreas de } \\
\text { nascentes }\end{array}$ & $\begin{array}{l}\text { Fundos de } \\
\text { vale }\end{array}$ \\
\hline Jardim de chuva & & - & - & - \\
\hline \multicolumn{5}{|l|}{ Canteiro Pluvial com infiltração } \\
\hline \multicolumn{5}{|l|}{ Canteiro Pluvial sem infiltração } \\
\hline \multicolumn{5}{|l|}{ Biovaleta } \\
\hline \multicolumn{5}{|l|}{ Cisterna } \\
\hline \multicolumn{5}{|l|}{ Telhado verde } \\
\hline Pavimento permeável & & - & & C \\
\hline Córrego recuperado & - & - & & \\
\hline Parque linear & - & - & & \\
\hline
\end{tabular}

\section{Legenda}

máximo desempenho na aplicação da tipologia, com vistas ao incentivo de processos naturais predominantes na zona ambiental.

aplicação compatível, mas com menor desempenho. Tipicamente, a tipologia maneja processos naturais predominantes que se mostram incompatíveis com a ocupação consolidada.

aplicação socialmente positiva, mas que não diz respeito ao objetivo coletivo de manter certa estabilidade da base biofísica da cidade.

aplicação que demanda mais estudos para verificação de desempenho na zona ambiental indicada.

- aplicação incompatível.

\section{ESTUDO DE CASO}

\section{ÁREA DE ESTUDO}

A área de estudo corresponde à bacia de drenagem do córrego Belini localizada na zona oeste do município de São Paulo. A bacia é gerida pelo Comitê da Bacia do Alto Tietê a sua área de drenagem total possui cerca de $2,0 \mathrm{~km}^{2}$, região apresentada na Figura 15. 


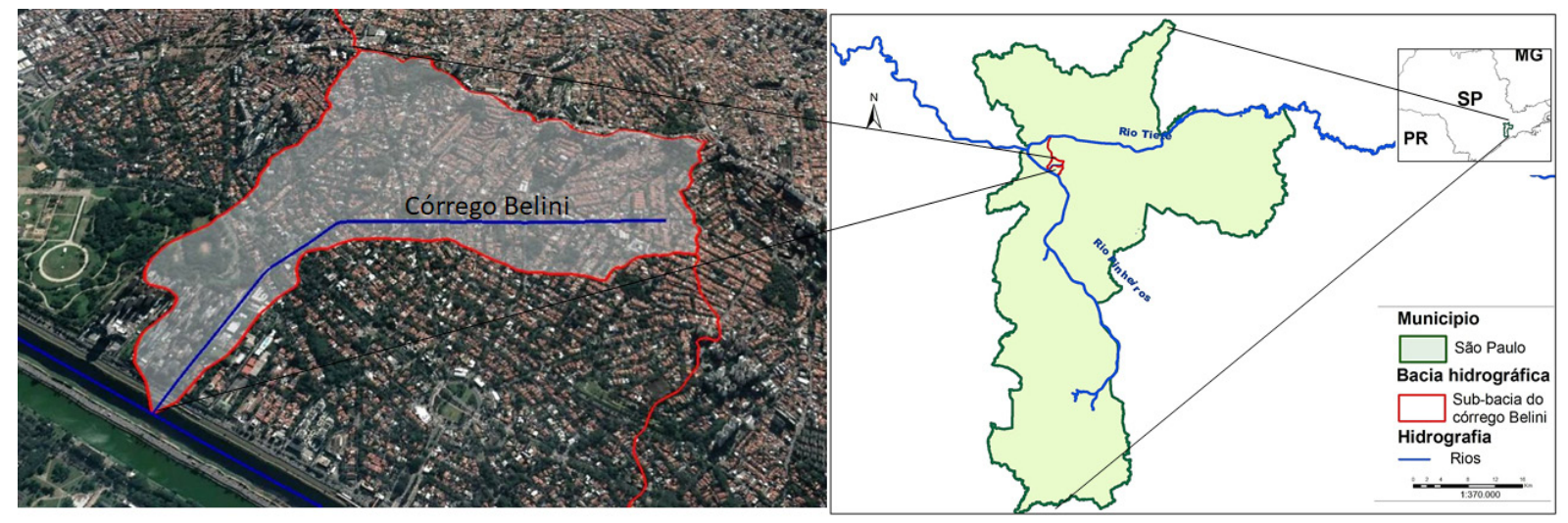

FIGURA 15. Bacia hidrográfica do córrego Bellini. Elaboração dos autores a partir da base do Geosampa (2018)

A seleção da bacia do córrego Belini como área de estudo foi realizada pelo fato de parte da população da bacia estar se organizado em grupos conscientes do poder da participação popular na busca por uma gestão ambiental dos espaços livres. Localizada no distrito de Alto de Pinheiros, é uma região cuja implantação foi realizada pela companhia City que durante o projeto dessa região, aproveitou-se de suas experiências bem-sucedidas de bairros ajardinados já implantados anteriormente em São Paulo, Prefeitura do Município de São Paulo (2018). Hoje com uma urbanização já consolidada, essa região é predominantemente residencial e horizontal.

Por estar localizado entre a várzea do rio Pinheiros e o espigão de São Paulo, o distrito tem topografia plana em grande parte de sua extensão e vegetação abundante, porém apresenta problemas de inundações.

\section{O ZONEAMENTO AMBIENTAL DA BACIA DO CÓRREGO BELLINI}

A proposta de intervenção na bacia de drenagem do córrego Belini baseia-se na metodologia proposta por Schutzer (2012) do zoneamento ambiental e adotada por Bonzi (2015) no que tange a infraestrutura verde, esta busca alterações na paisagem com vistas a uma região ecologicamente sustentável. E na questão de manejo no corpo d'água são usadas as considerações realizadas por Silva (2015).

Para a realização das análises de relevo fez-se uso de material obtido por geoprocessamento com o uso de ferramenta de Sistema de Informação Geográfica - SIG, no caso o software ArcGis. Dessa forma obteve modelo digital de elevação 
(MDE) do terreno (Figura 16), o mapa da declividade do terreno (Figura 17). O MDE e o mapa de declividades fornecem elementos das características do relevo essenciais para avaliação da tipologia mais adequada para a região, assim como os mapas da Figura 18 Carta Geotécnica e Figura 19 Recursos Vegetais, as informações obtidas nesses mapas foram relacionadas às informações do mapa geomorfológico de Aziz Ab'Sáber e da compartimentação do relevo proposta por Schutzer (2012) .

A bacia de drenagem do córrego Belini é pequena $\left(2,1 \mathrm{~km}^{2}\right)$ e apresenta características peculiares, o que facilita a análise.

No mapa geomorfológico de Aziz Ab'Sáber de 1957 e associado ao mapa de MDE (Figura 16) verifica-se que a bacia está em região que engloba as classificações: espigão central (800-820m); altas colinas e espigões secundários (750-795m); terraços fluviais do nível intermediário (745-750m); baixos terraços fluviais dos vales do Pinheiros (725-730m) e planícies dos aluviais do Pinheiros (720-722 m).

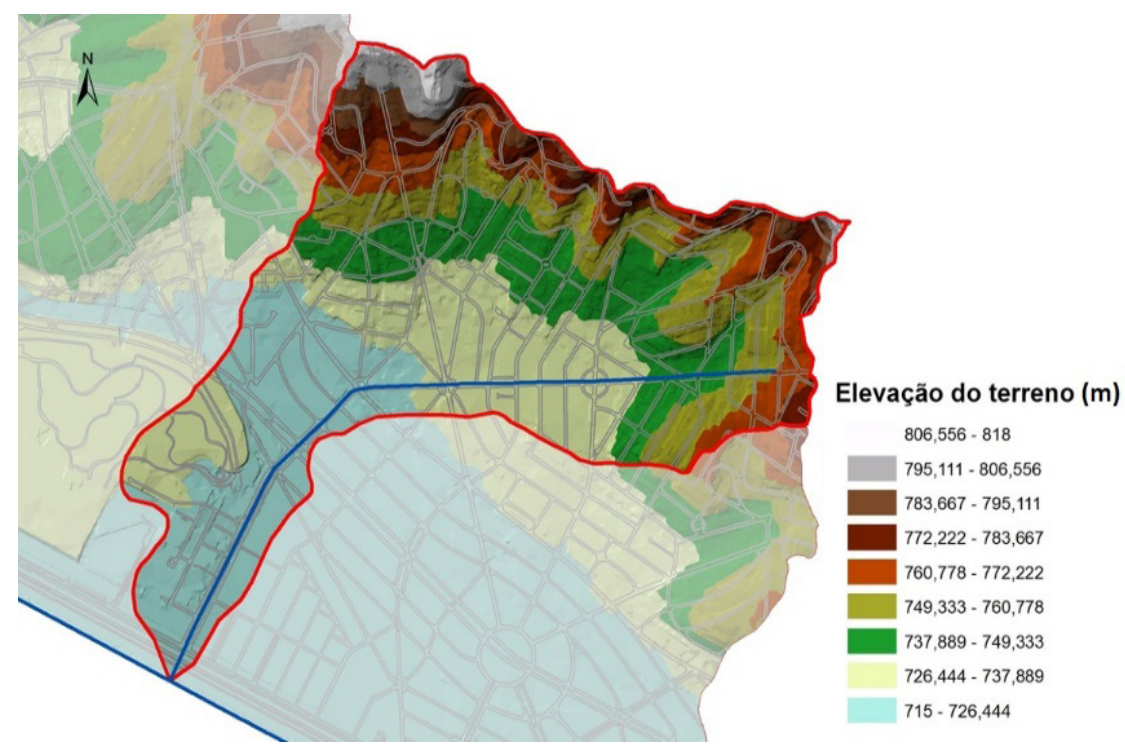

FIGURA 16. Modelo Digital de Elevação (MDE). Elaboração dos autores a partir da base do Geosampa (2018)

O mapa de declividade (Figura 17) indica que as vertentes mais altas estão na cabeceira do córrego seguindo em direção ao rio Pinheiros por uma região com declividades menos acentuada até chegar, um pouco antes da Avenida Diógenes Ribeiro de Lima, o trecho a partir do qual é uma região de planícies aluviais. 


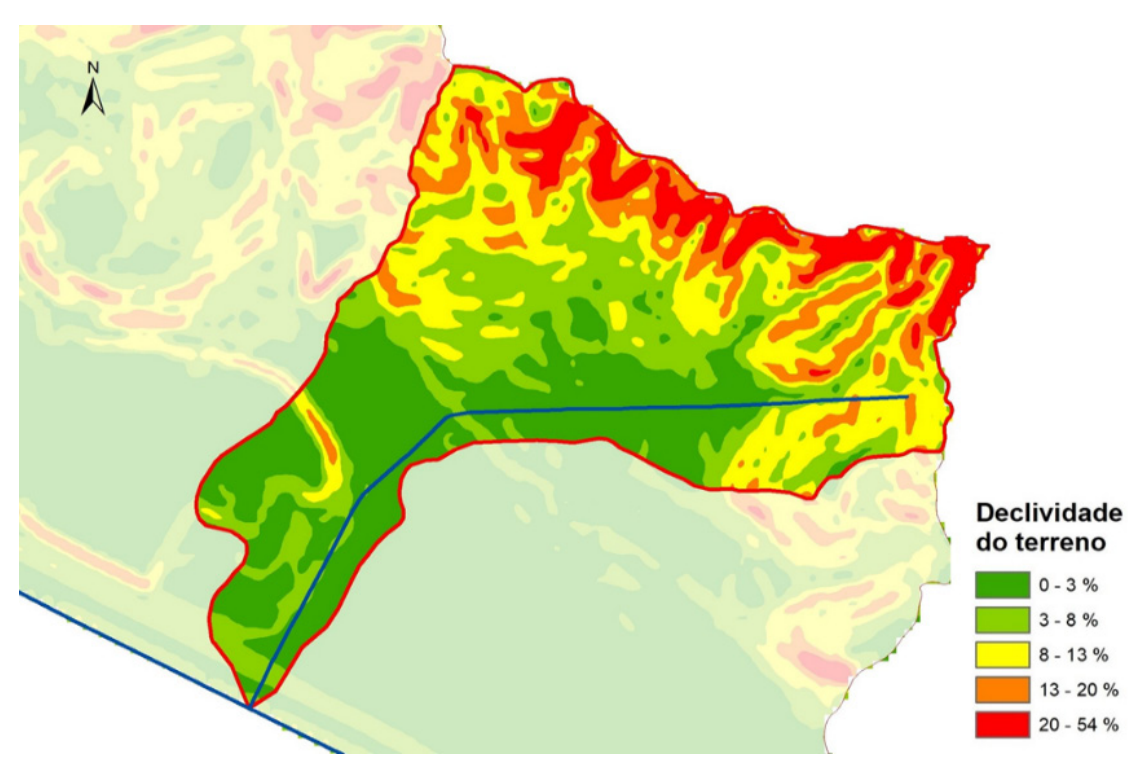

FIGURA 17. Mapa de declividade. Elaboração dos autores a partir da base do Geosampa (2018)

A carta geotécnica (Figura 18) fornece o tipo de solo da região, o que consiste num bom indicador para auxiliar na escolha do dispositivo de IEV que melhor se adequa quanto a questão de infiltração.

O mapa de recursos vegetais (Figura 19) indica o quanto a região é arborizada e com remanescentes da mata atlântica auxiliando na escolha de IEV de forma a constituir caminhos que favoreçam a flora e a fauna da região.

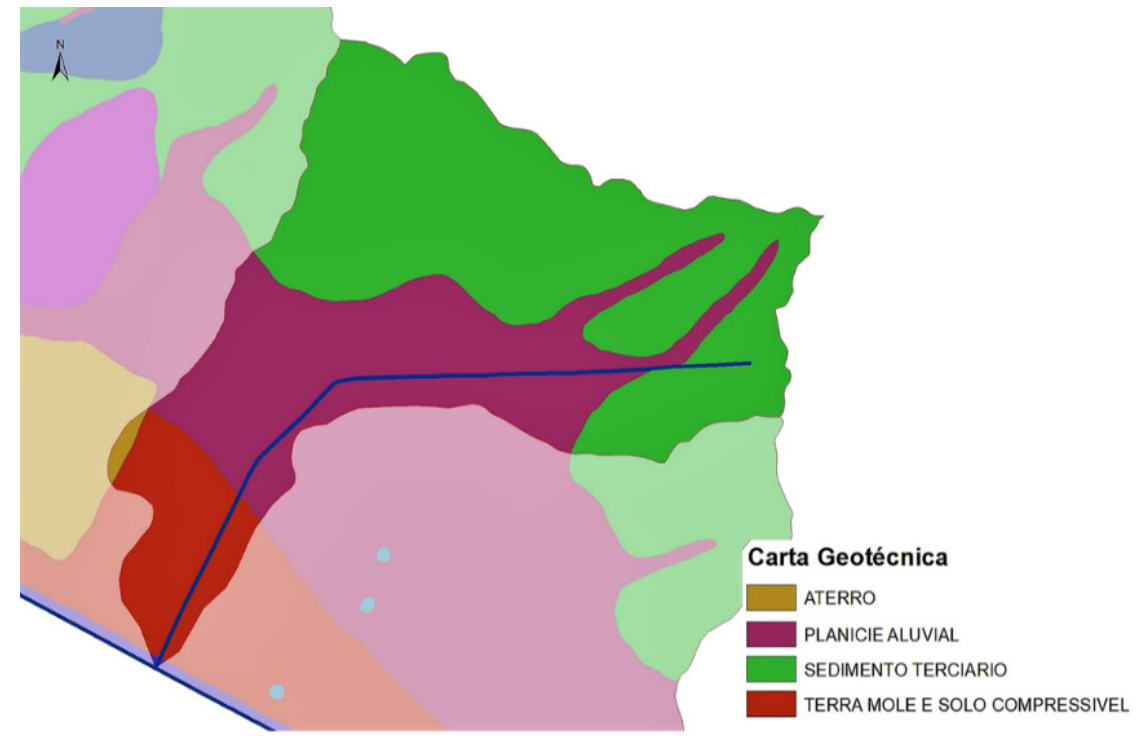

FIGURA 18. Carta Geotécnica. Elaboração dos autores a partir da base Geosampa (2018) 


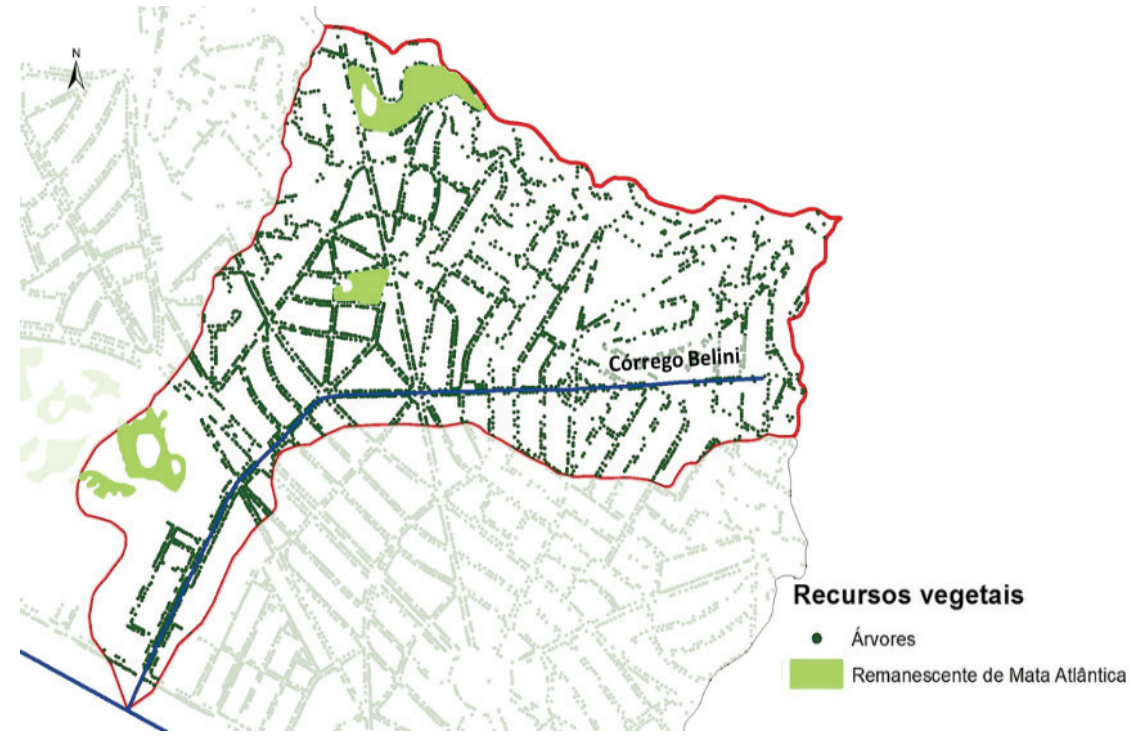

FIGURA 19. Recursos vegetais. Elaboração dos autores a partir da base Geosampa (2018)

É possível observar os compartimentos da bacia do córrego Bellini como proposto por Schutzer (2012) e apresentado na Figura 14, que nos fornece diretrizes seguras para a proposta de um plano de infraestrutura verde, que atenda as necessidades e comportamento natural e atual da bacia recorrendo ao zoneamento ambiental baseado nos processos naturais e na forma do relevo.

\section{DISPOSITIVOS DE INFRAESTRUTURA VERDE PARA MANEJO DE ÁGUAS URBANAS NA BACIA DO BELINI}

A análise do relevo da região indica que é uma região de alto potencial para a implantação de Infraestrutura Verde, assim foram elencados os dispositivos de IEV mais apropriado para cada um dos compartimentos identificados.

A cabeceira da bacia de drenagem do rio Belini está no espigão da cidade de São Paulo e é uma região de nascentes. Nessa região encontram-se as praças Waldir Azevedo, Engenheiro Norivaldo Pêra Geral, Sales Junior, Gastão Crusis, Francois Belanger e Carlos Monteiro Brisola são áreas nas quais umidade do local dever ser preservada, portanto deve ser incentivada a infiltração, mantendo os processos naturais já existentes nessa região, que está ligado a recarga das nascentes e do lençol freático, que contribui com a umidade do ar e do solo, mantem a vegetação e cria microclimas agradáveis que combatem as ilhas de calor. 
São áreas propícias para a implantação de jardins de chuva e pavimentos permeáveis com infiltração, que podem ser aplicadas nas ruas e nos lotes com o intuito de controlar o escoamento superficial. Deve-se buscar a transformação dessas áreas em áreas verdes, por serem áreas de natureza por excelência.

Os jardins de chuvas além das funções já apresentadas são dispositivos que devem ser aproveitados em todos os locais onde a topografia permitir, pois devem trabalhar como um filtro, contribuindo para a melhoria da qualidade da água oriunda do escoamento superficial e reduzindo a poluição difusa.

Nas regiões com cotas mais baixas, nas faixas intermediárias a indicação, de acordo com a metodologia é ideal para a implantação de biovaletas que farão a ligação dos jardins de chuva das áreas de cotas maiores à IEV dos locais de menores cotas.

A região mais a jusante após a delimitação da Avenida Diógenes Ribeiro de Lima, antiga estrada a Boiada, é uma região de planície aluvial do rio Pinheiros, na qual os processos de armazenamento de água são preponderantes sobre os processos de infiltração. Os excessos de água tendem a se acumular na superfície. Dado o alto índice de urbanização da região, propõem-se, para iniciar a recuperação da área a jusante da bacia após a praça Beethoven, uma medida ousada, que é a abertura do córrego e a criação de um parque linear do trecho que vai desde a praça Beethoven até a marginal Pinheiros.

Por toda a bacia deve-se incentivar o uso de microrreservatórios, pois são dispositivos de baixo custo e servem para a retenção da água de chuva não é infiltrada no próprio lote, e que pode ser aproveitada na rega de gramados e jardins. O dimensionamento destes reservatórios deve ser orientado de forma a não frustrar as expectativas dos futuros usuários.

\section{CONCLUSÕES E RECOMENDAÇÕES}

A área da bacia do córrego Belini tem potencial para a aplicação dos dispositivos de infraestrutura verde, sendo que foram realizadas propostas que devem servir de diretrizes para um estudo mais aprofundado até chegar ao projeto executivo. Local que possibilita de sua apropriação pela população, que em parte já vem atuando e se apropriando desses espaços juntamente com os movimentos sociais. 
Outros estudos devem ser realizados para a avalição do potencial da implantação de corredores verdes, para no futuro pensar na possibilidade da configuração de um mosaico de paisagem. Entender a dinâmica entre diversos atores que atuam na região, população e poder público e auxílio técnico para realização de projetos comunitários para a implementação de dispositivos de IEV.

Os problemas encontrados na região, apesar de poucos quando comparados com outras regiões paulistanas, são resultado de um processo de urbanização que desconsiderou a interação da cidade com a água, a preservação da biodiversidade e a conservação do microclima.

Ainda há de se observar o uso e ocupação do solo de acordo com o zoneamento da região onde predomina zona exclusivamente residencial e zona de corredor, o que possibilita a atuação maciça da população residente na transformação da região.

As propostas apresentadas são alternativas que buscam a harmonia entre os processos naturais e a ocupação da bacia, as quais consideram outras questões de serviços ambientais, não somente os convencionais de drenagem urbana.

Ainda, quando se leva em conta as dinâmicas sociais e movimentos que atuam na região, também fica claro que a aplicação da infraestrutura verde transcende os objetivos meramente ecológicos tornando uma rede de construção e apropriação social do meio urbano.

As diretrizes aqui apresentadas precisam ser detalhadas por intermédio de projeto específico antes de sua aplicação. Conjuntamente faz-se necessária a intervenção da concessionária de serviços de saneamento (SABESP), para que todo o esgoto da região seja coletado, interligado aos interceptores e conduzido para tratamento, contribuindo assim, para a melhoria de qualidade da água no córrego Belini.

\section{REFERÊNCIAS}

AB'SABER, A. N. Geomorfologia do Sítio Urbano de São Paulo. Tese (Doutorado) - Faculdade de Ciências e Letras, Universidade de São Paulo, Departamento de Geografia, São Paulo, 1957. 219p.

ANANDASIVAM, K.; CHEONG, C.F.Designing a creative learning environmental NTU's new Art, Design \& Media Library. The Electronic Libravi, vol 26 Issue:5 pp.650-661 
ARAÚJO, P.R. Análise experimental da eficiência dos pavimentos permeáveis na redução do escoamento superficial. Dissertação (Mestrado) - Instituto de Pesquisas Hidráulicas, Universidade Federal do Rio Grande do Sul, Porto Alegre, 1999.

BERGĖS, L.; ROCHE, P.; AVON, C. Corridors écologiques et conservation de la biodiversité, intérêts et limites pour la mise en place de la Trame verte et bleue. Sciences Eaux \& Territoires, n. 3, p. 34-39, 2010.

BONZI, R. S. Andar sobre Água Preta: a aplicação da infraestrutura verde em áreas densamente urbanizadas. Revista LabVerde. São Paulo: FAUUSP, n. 10, P. 105-132, 2015.

BONZI, R. S. O Zoneamento ambiental geomorfológico como método para planejar a infraestrutura verde em áreas densamente urbanizadas. Dissertação (Mestrado). Faculdade de Arquitetura e Urbanismo da Universidade de São Paulo, São Paulo. 2015.

CARINNA, S. S; ALMIR, F. R. Espaços livres nas margens de rios urbanos: Padrões de acessibilidade em Goiânia e Florianópolis XI Colóquio Quapá-SEL . Salvador: UFBA, 2016.

CORMIER, N. S; PELLEGRINO, P. R. M. Infra-estrutura verde: uma estratégia paisagística para a água urbana. Revista Paisagem e Ambiente. São Paulo: FAUUSP, n. 25, P. 127-142, 2008.

CAPUCCINI, E. Aplicazione di tecnologie BMP ai sistemi di drenaggio urbano. Tesi di Laurea (Idrologia Sotteranea) - Università di Bologna, Facolta'di Ingegneria, Corso di Laurea Specialistica in Ingegheria Civile, Bologna, 2009/10.

COSTA JUNIOR, L.L.; BARBASSA, A. P. Parâmetros de projeto de microrreservatório, de pavimento permeáveis e de previsão de enchentes urbanas. Eng.sanit.ambient., v. 11, n. 1 p. 46-54, jan./mar. 2006.

ENVIRONMENTAL SERVICES. Disponível em :<https://www.portlandoregon.gov/bes/article/123776>. Acesso em: 19 de maio de 2018.

FALKENMARK, Malin; ROCKSTRÖM, Johan. The new blue and green water paradigm: Breaking new ground for water resources planning and management. 2006.

FOLHA DE SÃO PAULO. Disponível em :< http://www1.folha.uol.com.br/cotidiano/2013/02/1231027com-agua-nas-canelas-pais-tiram-nas-costas-filhos-ilhados-em-escola-de-pinheiros.shtml>. Acesso em: 19 de maio de 2018.

FRANCO, M.A.R. Infraestrutura Verde em São Paulo: o caso do Corredor Verde Ibirapuera-Villa Lobos. Revista LABVERDE, São Paulo - SP, n.1, p.135- 154, 2010.

FRIEDRICH, D. O parque linear como instrumento de planejamento e gestão de áreas de fundo de vale urbanas. Dissertação (Mestrado). Universidade Federal do Rio Grande do Sul, Porto Alegre. 2007. 
LOCATELLI, M.M.; SANCHES, P.M.; POLIZEL, J.L.; SILVA FILHO, D.F. Planejamento de Espaços Verdes para Minimização do Escoamento Superficial de Águas Pluviais. Revista LABVERDE, São Paulo - SP, v.8, n.2, p.75-89, 2017.

MAGALHÃES, D.M. Análise dos espaços verdes remanescentes na mancha urbana conurbada de Belo Horizonte - MG apoiada por métricas de paisagem. Dissertação (Mestrado). Universidade Federal de Minas Gerais, Belo Horizonte. 2013.

MARTINS, M.J. Gerenciamento de recursos hídricos e drenagem urbana no município de São João de Meriti: análise espacial do efeito da implementação de microrreservatórios em lotes sobre as inundações. Dissertação (Mestrado em Engenharia) - Universidade Federal do Rio de Janeiro, Programa de Pós-Graduação em Engenharia Civil, Rio de Porto Alegre, 2004.

MARQUES, C. E. B. Proposta de método para a formulação de planos diretores de drenagem urbana. Dissertação (Mestrado) - Faculdade de Tecnologia, Universidade de Brasília, Distrito Federal, 2006.

MENDONÇA, R. G. Paisagem Fluvial Urbana: percursos e percepções na cidade de São Paulo. Dissertação (Mestrado). Faculdade de Arquitetura e Urbanismo da Universidade de São Paulo, São Paulo. 2015.

MOTA, S. Gestão ambiental de recursos hídrico. 3, ed Rio de Janeiro: ABES,2008.

MOURA, N. C. B. Biorretenção: tecnologia ambiental urbana para manejo das águas de chuva. (Tese de Doutorado). Faculdade de Arquitetura e Urbanismo, Universidade de São Paulo, São Paulo, 2014.

OHNUMA JÚNIOR, A.K. Medidas não-convencionais de reservação d'água e controle da poluição hídrica em lotes domiciliares. Tese (Doutorado) - Escola de Engenharia São Carlos da Universidade de São Paulo. São Carlos. 2008.

OSTROWSKY, M.S.B. Sistemática Integrada para Controle de Inundações em Sub-bacias Hidrográficas Urbanas - Estudo de Caso: A Bacia do Córrego Pirajuçara, sob o enfoque da integração de obras com ações de educação e percepção ambiental. Tese (Doutorado) - Faculdade de Arquitetura e Urbanismo da USP. Estruturas Ambientais e Urbanas. São Paulo. 2000.

PEREIRA, M. C. S. et al. Influência do Controle da Impermeabilização no Custo do Sistema de Drenagem. In: XX SIMPÓSIO BRASILEIRO DE RECURSOS HÍDRICOS, 2013, Bento Gonçalves-/S.

PINKHAM, R. 21st Century Water Systems: Scenarios, Visions and Drivers. Snowmass: Rocky Mountain Institute, 1999.

GEOSAMPA - PMSP. Disponível em:< http://geosampa.prefeitura.sp.gov.br >. Acesso em: 20 de maio de 2018. 
SECRETARIA DO VERDE E DO MEIO AMBIENTE - SVMA. Disponível em:< https://www.prefeitura. sp.gov.br/cidade/secretarias/meio_ambiente/parques/index.php?p=144010>. Acesso em: 20 de maio de 2018.

SILVA, J.C.A. Bacias Hidrográficas Urbanizadas: Renaturalização, Revitalização e Recuperação. Um Estudo da Bacia do Jaguaré. Tese (Doutorado) - Escola Politécnica da Universidade de São Paulo. Departamento de Engenharia Hidráulica e Ambiental. 2017.

SILVERIO, M. Projeto de Infraestrutura Urbana na Bacia Hidrográfica do Córrego Judas, São Paulo. Revista LABVERDE, São Paulo - SP, n.4, p.175- 205, 2012.

TUCCI, C.E.M. Inundações Urbanas. Porto Alegre: ABRH/RHAMA, 2007.

UCONN - UNIVERSITY OF CONNECTICUT. Disponível em :< http://nemo.uconn.edu/raingardens/index.htm>. Acesso em: 19 de maio de 2018.

URBONAS, B.; STAHRE, P. Stormwater best management practices and detention. For water quality, drainage and co management. New Jersety: Prentice Hall, 1992.

U.S. ENVIRONMENTAL PROTECTION AGENCY. Greening EPA. Disponível em :< http://www.epa. gov/oaintrnt/index.htm>. Acesso em: 20 de maio de 2018.

VIRGILIIS, A.L.C. Procedimentos de projeto e execução de pavimentos permeáveis visando retenção e amortecimento de picos de cheias. Dissertação (Mestrado) - Escola Politécnica da USP. Departamento de Engenharia de Transportes. São Paulo. 2009. 